\title{
Thiosphaera pantotropha gen. nov. sp. nov., a Facultatively Anaerobic, Facultatively Autotrophic Sulphur Bacterium
}

\author{
By LESLEY A. ROBERTSON AND J. GIJS KUENEN* \\ Laboratory of Microbiology, Delft University of Technology, Julianalaan 67a, 2628 BC, Delft, \\ The Netherlands
}

(Received 21 March 1983; revised 20 April 1983)

\begin{abstract}
During studies on a desulphurizing, denitrifying effluent-treatment system, an organism which is able to grow aerobically and anaerobically on reduced sulphur compounds and hydrogen, while fixing carbon dioxide, was isolated. The new isolate is also capable of mixotrophic and heterotrophic growth on a wide range of substrates, and is therefore a facultatively aerobic, facultative autotroph. Comparisons with two similar species, Thiobacillus A2 and Paracoccus denitrificans, showed that the new isolate is significantly different from the other two, and merits separate classification. In view of its ability to oxidize reduced sulphur compounds, and because it is a chain-forming coccus rather than a rod, the new isolate has been given the generic name of Thiosphaera, and the species name pantotropha in recognition of its wide range of possible substrates.
\end{abstract}

\section{INTRODUCTION}

In various types of industrial effluent, both nitrate and reduced sulphur compounds can be an environmental problem. Until now, methanol has been a popular electron donor in denitrification plants (Rhee \& Fuhs, 1978), but in view of the rising cost of methanol, attention is turning to cheaper additives such as sulphur (Batchelor \& Lawrence, 1978). This type of system would clearly involve bacteria similar to the thiobacilli and, where the sulphur compounds are already present in the effluent, the advantages are obvious. We have studied a pilot-plant-scale reactor of this type from a practical management viewpoint and as an ecophysiological problem.

The population in such a sulphide-oxidizing effluent treatment system is likely to be complex, and in addition to the 'black box' type of approach, it is therefore necessary to start with pure culture studies of suitable model organisms.

Almost all of the work on denitrification by colourless sulphur bacteria has concentrated on the obligately chemolithotrophic species such as Thiobacillus denitrificans (Aminuddin \& Nicholas, 1973; Ishaque \& Aleem, 1973) and, with only a few exceptions (Timmer ten Hoor, 1977; Justin \& Kelly, 1978), was done in batch culture. Very little is known about other physiological types and, with the exception of Thiobacillus A2 (Taylor \& Hoare, 1969), the only recognized denitrifying sulphur bacteria are obligate autotrophs (Timmer ten Hoor, 1975; Vishniac, 1974; Taylor et al., 1971). A thermophilic organism, Thermothrix thiopara, was reported to be able to oxidize but not to grow anaerobically on reduced sulphur compounds (Brannan \& Caldwell, 1980). Taylor \& Hoare (1969), when describing Thiobacillus A2, stated that although this organism behaved as a facultative autotroph under aerobic conditions, it was only able to denitrify when growing heterotrophically.

Recent studies on enrichment cultures and simple mixtures of physiologically different thiobacilli indicated that the facultative chemolithotrophs may have a competitive advantage over their obligately autotrophic counterparts if mixotrophic growth on inorganic sulphur

Abbreviation: RuBPcase, ribulosebisphosphate carboxylase 
compounds and organic substrates is possible, or if autotrophic and heterotrophic growth conditions frequently alternate (Gottschal et al., 1979; Beudeker et al., 1982). If a similar principle can be applied to anaerobic cultures of denitrifying bacteria, the effluent treatment system under study would appear to provide conditions which would promote the selection of denitrifying, facultatively chemolithotrophic, sulphur bacteria. In order to test this, the first phase of study was to attempt the isolation of such an organism from the effluent-treatment system, and the second stage to compare the properties and competitive success with those of an obligately autotrophic denitrifyer such as $T$. denitrificans.

This paper describes the isolation and characterization of an organism which is capable of both facultatively autotrophic and facultatively anaerobic growth. This isolate is compared with two species which appear to be closely related, Thiobacillus A2 and Paracoccus denitrificans.

\section{METHODS}

Organisms. Thiobacillus A2 (Delft culture collection LMD 80.62) was originally obtained from B. F. Taylor. Paracoccus denitrificans was obtained from the Delft culture collection (LMD 22.21) and is the strain originally isolated by Beijerinck (1910). Bacterium Al was a kind gift from P. W. Trudgill and is one of the strains used by Taylor et al. (1980).

Media. Thiobacillus A2 and the new isolate were grown in the medium described by Taylor \& Hoare (1969), but with phenol red omitted. It contained $\left(\mathrm{g} \mathrm{l}^{-1}\right): \mathrm{Na}_{2} \mathrm{HPO}_{4} .7 \mathrm{H}_{2} \mathrm{O}, 7 \cdot 9 ; \mathrm{KH}_{2} \mathrm{PO}_{4}, 1 \cdot 5 ; \mathrm{NH}_{4} \mathrm{Cl}, 0 \cdot 3 ; \mathrm{MgSO}_{4} .7 \mathrm{H}_{2} \mathrm{O}$, 0.1 ; and $2 \mathrm{ml}$ trace element solution (Vishniac \& Santer, 1957). Paracoccus denitrificans and bacterium A1 were grown in the medium described by Taylor $e t$ al. (1971) for $T$. denitrificans. This contained ( $\left.1^{-1}\right): \mathrm{KNO}_{3}, 2 \cdot 0$; $\mathrm{KH}_{2} \mathrm{PO}_{4}, 2 \cdot 0 ; \mathrm{NaHCO}_{3}, 1 \cdot 0 ; \mathrm{NH}_{4} \mathrm{Cl}, 1 \cdot 0 ; \mathrm{MgSO}_{4} .7 \mathrm{H}_{2} \mathrm{O}, 0 \cdot 8 ;$ and $2 \mathrm{ml}$ trace element solution (Vishniac \& Santer, 1957). In both cases, the trace element solution used was as described by Vishniac \& Santer (1957), except that it contained $2.2 \mathrm{~g}$ rather than the original $22 \mathrm{~g}$ of $\mathrm{ZnSO}_{4} .7 \mathrm{H}_{2} \mathrm{O}$. Solid media were prepared by the addition of $2 \%$ Difco Bacto agar to the appropriate liquid medium. Unless otherwise stated, all chemicals were of analytical grade.

The utilization of different substrates by strain GB17 (substrate screening) was tested in liquid medium as it was found that the presence of agar gave false positive results. Substrates for testing were used at a concentration of $0.1 \%$, unless otherwise stated. Thiosulphate and sulphide were used at concentrations of $10 \mathrm{~mm}$. Growth on sulphite was tested at concentrations between 2.5 and $20 \mathrm{~mm}$. Growth on $\mathrm{H}_{2}$ was tested in a mineral medium containing $\left(\mathrm{g} \mathrm{l}^{-1}\right): \mathrm{KH}_{2} \mathrm{PO}_{4}, 2 \cdot 3 ; \mathrm{NaHPO}_{4} .2 \mathrm{H}_{2} \mathrm{O}, 2.9 ; \mathrm{NH}_{4} \mathrm{Cl}, 1 \cdot 0 ; \mathrm{MgSO}_{4} .7 \mathrm{H}_{2} \mathrm{O}, 0 \cdot 5 ; \mathrm{NaHCO}_{3}, 0 \cdot 5$; $\mathrm{CaCl}_{2} \cdot 2 \mathrm{H}_{2} \mathrm{O}, 0 \cdot 01$; and ferric ammonium citrate, $0 \cdot 05$. Unless otherwise stated, $20 \mathrm{~mm}-\mathrm{KNO}_{3}$ was added to all batch cultures for anaerobic growth. $\mathrm{KNO}_{2}$ utilization was tested at concentrations between 1 and $20 \mathrm{~mm}$. Nitrogen sources were tested using the normal media, but with the $\mathrm{NH}_{4} \mathrm{Cl}$ omitted.

The medium supplied to the chemostat contained $\left(\mathrm{g} \mathrm{l}^{-1}\right): \mathrm{K}_{2} \mathrm{HPO}_{4}, 0.8 ; \mathrm{KH}_{2} \mathrm{PO}_{4}, 0.3 ; \mathrm{NH}_{4} \mathrm{Cl}, 0.4$; $\mathrm{MgSO}_{4} .7 \mathrm{H}_{2} \mathrm{O}, 0.4$; and $2 \mathrm{ml}$ trace element solution. Acetate $(10 \mathrm{mM})$ and thiosulphate $(10 \mathrm{~mm})$ were used as the electron donors, and $\mathrm{KNO}_{3}(32 \mathrm{mM})$ as the electron acceptor.

Thiobacillus A2 and $P$. denitrificans were incubated at $30^{\circ} \mathrm{C}$. Except during the determination of its growth range, strain GB17 was incubated at $37^{\circ} \mathrm{C}$. All aerobic cultures were incubated on a rotary shaker.

For the continuous flow enrichment, a Biolafitte glass chemostat with a working volume of 1.51 was used. Dissolved oxygen, $\mathrm{pH}$ and $\mathrm{OD}$ of the culture were continuously monitored. The $\mathrm{pH}$ was maintained at 8.0 by automatic titration with $1 \mathrm{M}-\mathrm{NaOH}$. Anaerobic conditions were maintained by continuous flushing with nitrogen from which all traces of oxygen had been removed by a catalyst (BASF-Katalysator R3-11). The medium reservoirs and $\mathrm{NaOH}$ supply were also kept under nitrogen. To prevent oxygen contamination, all tubing on the fermenter except the pump tubing was made of Teflon with butyl rubber joints. The pump tubing was of Tygon. The dilution rate was $0.03 \mathrm{~h}^{-1}$. The enrichment culture was inoculated with $10 \mathrm{ml}$ of material from a denitrifying, desulphurizing effluent-treatment column.

Miscellaneous methods. Sulphide and sulphite were determined as described by Trüper \& Schlegel (1964) and thiosulphate by the method described by Sörbo (1957). Acetate was determined with acetyl-coenzyme A synthetase using a test kit (Boehringer). Nitrate was measured with a nitrate electrode (Radiometer Selectrode $S$ ) and nitrite with the Griess-Romijn reagent (Griess-Romijn-van Eck, 1966). Standard taxonomic parameters were checked with the API20B and API50CH arrays of routine metabolic tests (API Benelux). The percentage GC was determined from the melting point $\left(T_{\mathrm{m}}\right)$ of the DNA. Anaerobic conditions for batch culture were established using the Becton-Dickinson GasPak or the Oxoid G.A.S. system. In all cases, inoculated medium which lacked a substrate was used as a control. The gas mixture used for aerobic growth on hydrogen contained $(\%, \mathrm{v} / \mathrm{v}): \mathrm{H}_{2}, 65$; $\mathrm{N}_{2}, 24 ; \mathrm{CO}_{2}, 5$; and $\mathrm{O}_{2}, 6$. For anaerobic growth, $95 \% \mathrm{H}_{2}$ and $5 \% \mathrm{CO}_{2}(\mathrm{v} / \mathrm{v})$ was used.

The rate of gas production under anaerobic conditions was measured using standard manometric techniques. 
Nitrate was added at the same time as the substrate to prevent endogenous gas production before the start of the experiment.

Ribulosebisphosphate carboxylase (RuBPcase) activity in cell extracts was determined by the method described by Beudeker et al. (1980).

\section{RESULTS}

The new isolate was obtained from a denitrifying, sulphide-oxidizing, effluent-treatment pilot plant at Gist Brocades, Delft, by enrichment in an anaerobic chemostat with thiosulphate and acetate as growth-limiting substrates, followed by selective streaking on thiosulphate and acetate plates, which were then incubated anaerobically. It was chosen from a group of isolates for further study since it lacked any requirement for vitamins or other supplements, and because it was capable of both autotrophic and heterotrophic growth under aerobic and anaerobic conditions. Its distinctive morphology allows it to be easily distinguished in phase-contrast microscope preparations of material from the effluent-treatment column where it seems to form a significant part of the population. It has since been re-isolated from many samples taken from the enrichment culture, and also from samples direct from the column. For convenience, it is referred to as strain GB17.

Strain GB17 is a non-motile, Gram-negative coccus $(0.7 \times 0.9 \mu \mathrm{m})$ which is frequently seen in pairs and long chains (Figs 1 and 2). It does not contain a complex membrane system, and carboxysomes have not been observed (Fig 3 ). The isolate has a \% GC ratio of 65.8-66.0, which is in the same range as other facultative chemolithotrophs such as Thiobacillus novellus (62-68), Thiobacillus A2 (65-68) and Paracoccus denitrificans (66.5).

On acetate or thiosulphate agar, strain GB17 grows as off-white, translucent, round, entire, wet-looking colonies. It can grow over a $\mathrm{pH}$ range between 6.5 and 10.5 with an optimum at 8.0 , and the temperature range permitting growth lies between 15 and $42{ }^{\circ} \mathrm{C}$ with an optimum at $37^{\circ} \mathrm{C}$. It is both oxidase- and catalase-positive. The results of a comparison between strain GB17, Thiobacillus A2 and $P$. denitrificans using the API20B system are shown in Table 1.

All three organisms can use nitrate and nitrite as electron acceptors for anaerobic growth on heterotrophic substrates, but only strain GB17 could do so on sulphide or thiosulphate. Strain GB17 and Thiobacillus A2 can also use fumarate instead of nitrate, whereas $P$. denitrificans cannot. Fermentation did not occur.

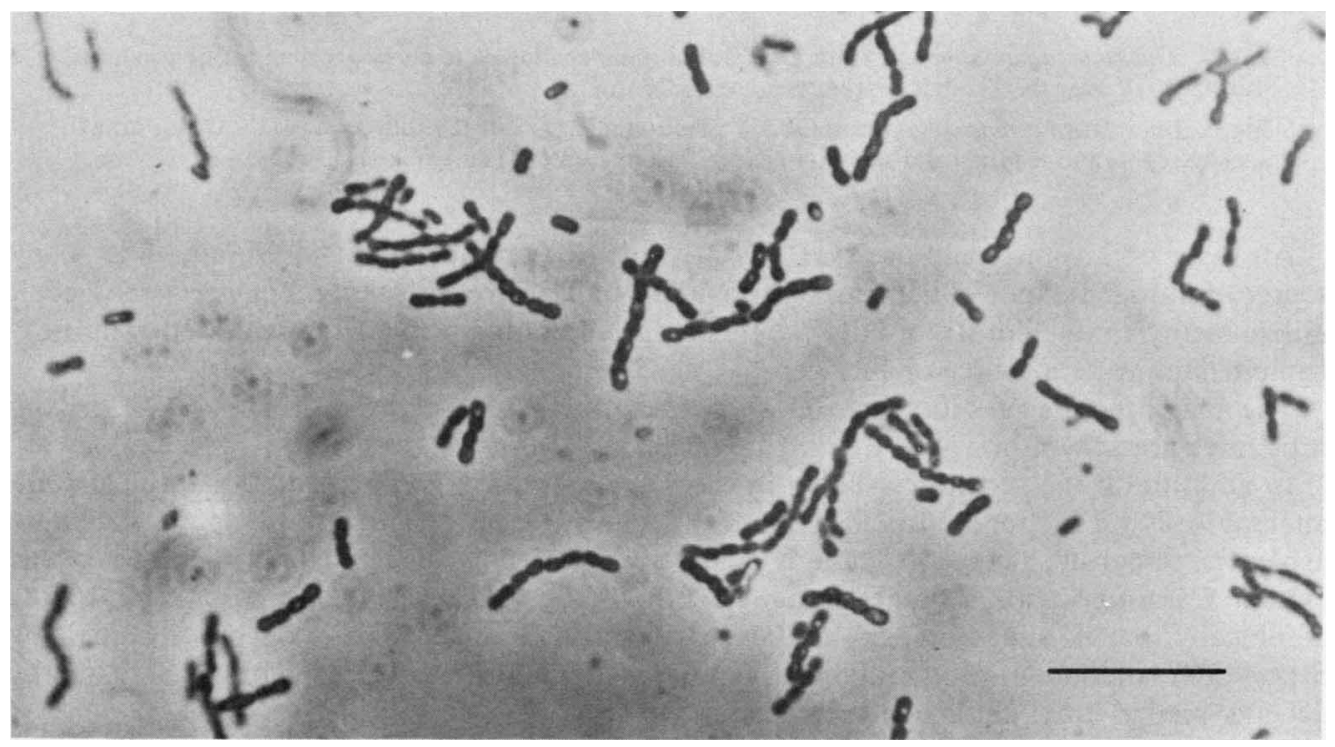

Fig. 1. Thiosphaera pantotropha (strain GB17). Positive phase-contrast micrograph showing the chainforming characteristic of growth on rich media. The bar marker represents $10 \mu \mathrm{m}$. 


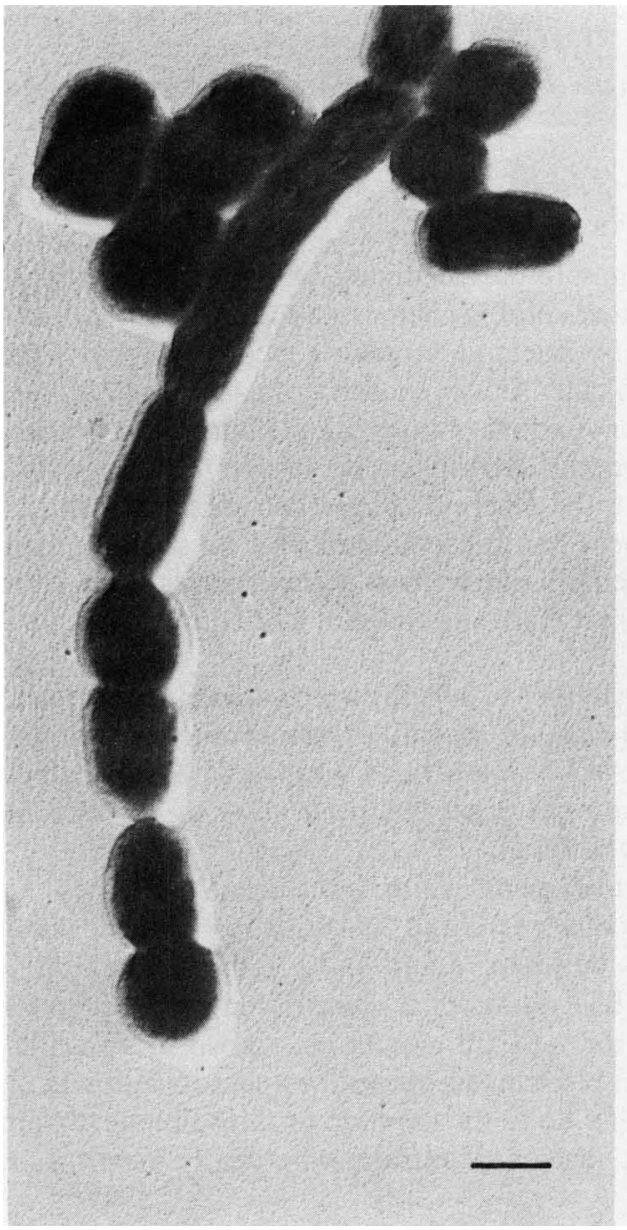

Fig. 2

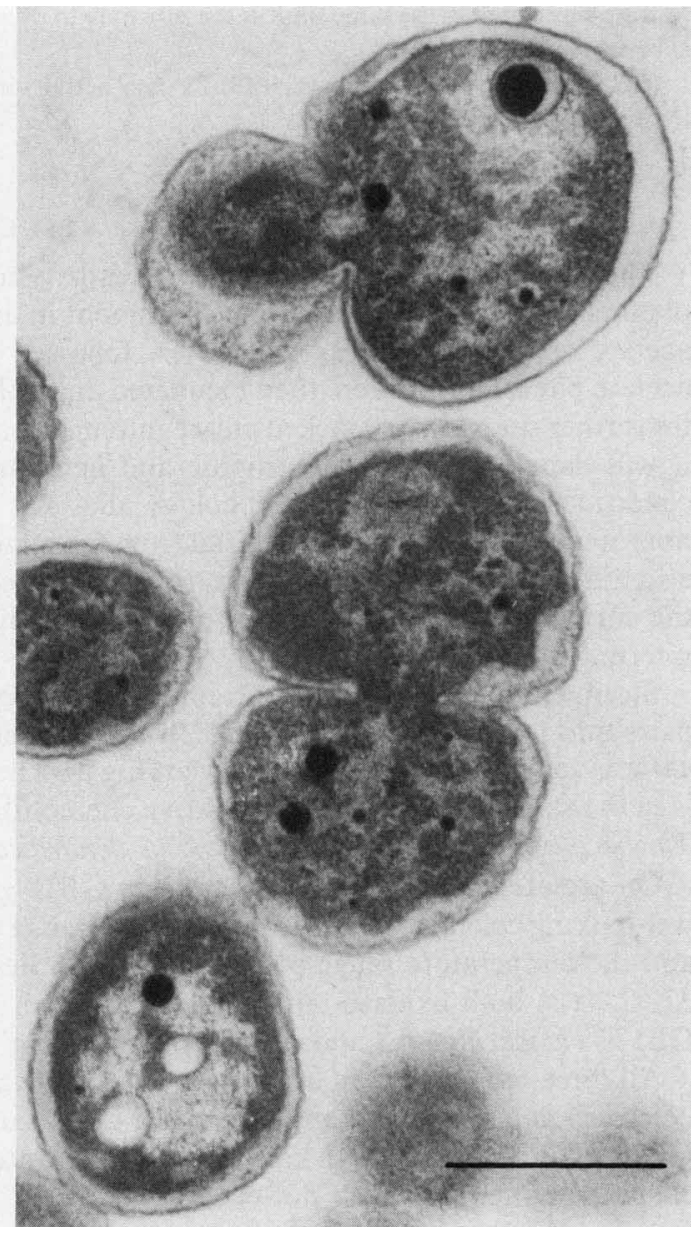

Fig. 3

Fig. 2. Thiosphaera pantotropha (strain GB17). Platinum-shadowed to show atypical forms produced during rapid growth. The bar marker represents $0.5 \mu \mathrm{m}$.

Fig. 3. Thiosphaera pantotropha (strain GB17). Electron micrograph of a thin section $\left(1 \% \mathrm{OsO}_{4}\right.$, uranyl acetate, epon and lead citrate) showing lack of carboxysomes. The bar marker represents $0.5 \mu \mathrm{m}$.

All three organisms could use $\mathrm{NH}_{4}^{+}, \mathrm{NO}_{3}^{-}$, urea, Casamino-acids and glutamate as a sole source of nitrogen. None of them grew without an added nitrogen supply. Thiobacillus A2 could utilize methylamine, but strain GB17 could not. Neither organism could use dimethylamine or trimethylamine as a source of nitrogen.

The major points of difference between the growth of the three organisms on organic substrates are shown in Table 2.

In addition to the substrates shown in the Tables, strain GB17 grew both aerobically and anaerobically on hydrogen, fructose, mannose, glucose, acetate, lactate, pyruvate, succinate, aspartate, fumarate, gluconate, glutamate, alanine, histidine, isoleucine, leucine, proline, yeast extract, Casamino acids, acetone, propane-1,2-diol, propan-2-ol, acetol and propionate. It grew aerobically, but not anaerobically on benzoate, and only anaerobically on propionaldehyde. Strain GB17 did not grow on arabinose, lactose, methanol, methane, pimelate, oxalate, methyl acetate, methyl ethyl ketone or propylene oxide.

All three strains could grow aerobically with thiosulphate or sulphide as an electron donor, but only strain GB17 grew anaerobically with either substrate as the sole source of energy. Sulphur 
Table 1. Different reactions shown by the three species when screened with the API2OB system

$$
\text { Property* }
$$

\section{Organism}

$$
\text { GEL NIT ONP }
$$

Strain GB17

$P$. denitrificans

Thiobacillus A2

$$
\begin{array}{ll}
- & + \\
- & +
\end{array}
$$

+
+
+

MNE SOR GLY $\begin{array}{ccc}- & + & - \\ - & - & - \\ - & + & +\end{array}$

$\begin{array}{cccc}+ & + & + & + \\ - & - & - & - \\ + & + & + & +\end{array}$

ox
CAT COC GRAM

Strain GB17

$P$. denitrificans

Thiobacillus A2

$-$

$$
\text { URE IND }
$$

VP CIT

$\begin{array}{lll}+ & - & + \\ - & + & + \\ - & + & +\end{array}$

AMD RHA GAL

* Abbreviations: GEL, gelatine liquefaction. NIT, nitrate reduction. ONPG, $\beta$-galactosidase present. Acid produced from the following carbohydrates: SAC, saccharose; ARA, L(+)-arabinose; MAN, mannitol; FRU, fructose; GLU, glucose; MAL, maltose; AMD, starch; RHA, rhamnose; GAL, galactose; MNE, mannose; SOR, sorbitol; GLY, glycerol. URE, urease present. IND, indole produced by a tryptophanase. $\mathrm{H}_{2} \mathrm{~S}$, hydrogen sulphide

\begin{tabular}{|c|c|c|c|c|c|c|}
\hline \multirow[b]{2}{*}{ Substrate } & \multicolumn{2}{|c|}{ Strain GB17 } & \multicolumn{2}{|c|}{ Thiobacillus A2 } & \multicolumn{2}{|c|}{ P. denitrificans } \\
\hline & Aerobic & Anaerobic & Aerobic & Anaerobic & Aerobic & Anaerobic \\
\hline Adipate & + & - & - & - & + & + \\
\hline Arabinose & - & - & - & - & + & + \\
\hline Citrate & - & - & + & + & + & - \\
\hline Galactose & - & - & + & + & + & + \\
\hline Serine & + & + & + & + & - & - \\
\hline Mannose & + & + & + & + & - & - \\
\hline Dulcitol & - & - & + & + & + & + \\
\hline Glycogen & - & - & + & + & + & + \\
\hline Formate & - & - & + & + & + & - \\
\hline
\end{tabular}
production. VP, acetoin production. CIT, citrate utilization. OX, cytochrome oxidase present. CAT, catalase present. COC, coccoid form. GRAM, reaction to Gram's stain.

Table 2. Major differences in the growth of the three species on organic substrates

was not observed in any of the cultures. None of the organisms grew on sulphite at the levels tested. An anaerobic batch culture of strain GB17 on thiosulphate gave a protein yield of $2.67 \mathrm{~g}$ (mol substrate) ${ }^{-1}$. This is equivalent to approximately $4.9 \mathrm{~g}$ dry wt per mol thiosulphate consumed assuming a biomass protein content of $50 \%$.

Aerobically grown strain GB17 was capable of denitrifying on acetate, thiosulphate, and mixtures of the two (Figs 4 and 5). However, in the presence of sulphide, gas production was lower (not shown). This is essentially in agreement with the results obtained with Pseudomonas perfectomarinus (Sørenson et al., 1980). Nitrogen release began immediately after the addition of nitrate and substrate, and continued until either the single energy source or the nitrate, when mixed substrates were involved, was exhausted. In contrast, Thiobacillus A2 required a 4 to $5 \mathrm{~h}$ lag phase before gas production began. Again, nitrogen release in the heterotrophic and mixotrophic vessels continued until the acetate or nitrate became exhausted, but little or no nitrogen was produced by the cells receiving thiosulphate. The rate of gas production by Thiobacillus A2 was much lower than that by similar preparations of strain GB17, requiring up to $20 \mathrm{~h}$ for completion. The only strain GB17 preparation requiring this length of time was that incubated with thiosulphate. In all cases the results obtained depended on the history of the culture, the influence of thiosulphate only being evident in those cultures which had been grown in the presence of thiosulphate or sulphide (Fig. 4). 


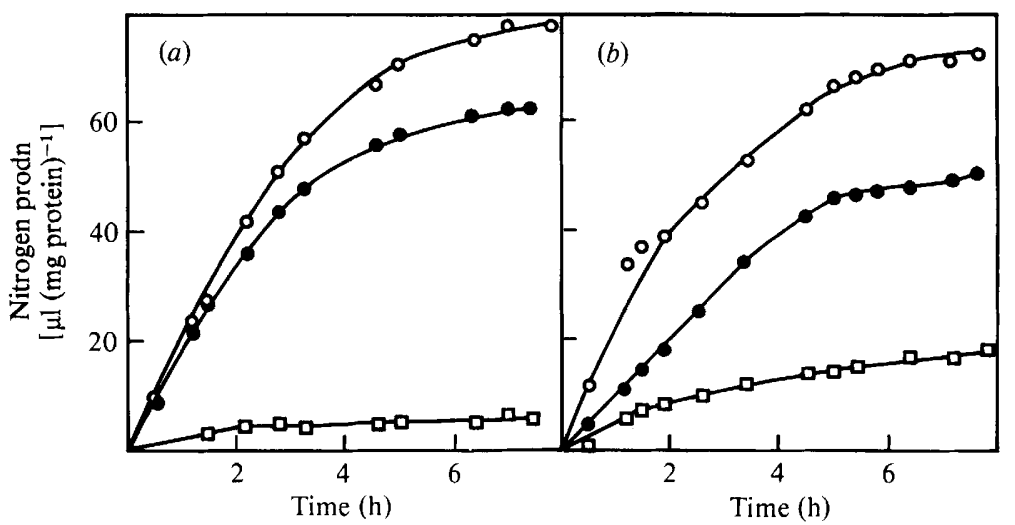

Fig. 4. Typical gas production curves obtained with Thiosphaera pantotropha (strain GB17) pregrown aerobically in the presence of nitrate. (a) Cells grown on acetate; $(b)$ cells grown on a mixture of acetate and thiosulphate. Gas production from acetate $(\odot)$, thiosulphate $(\square)$ and both acetate and thiosulphate (O) supplied as substrate.

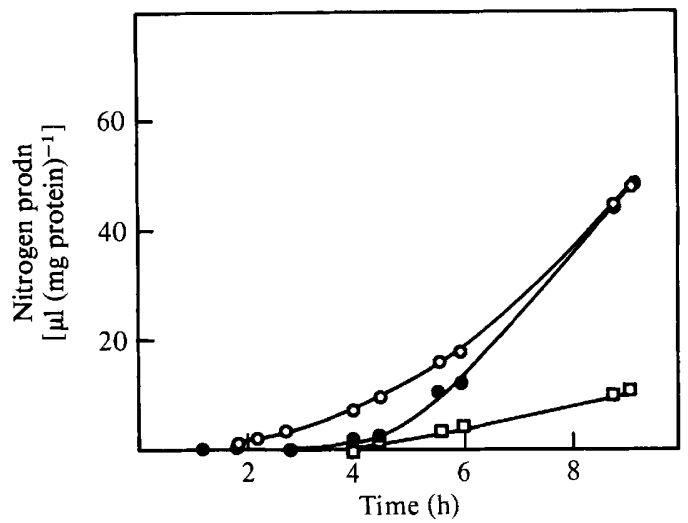

Fig. 5. Gas production obtained with Thiobacillus A2, pregrown aerobically with nitrate, acetate and thiosulphate. Symbols as in Fig. 4.

Table 3. Anaerobic consumption of thiosulphate by Thiobacillus A2 under mixotrophic conditions showing that thiosulphate is consumed with an increase in biomass and elimination of excess nitrate in the cultures

$\begin{array}{ccccccc}\begin{array}{c}\text { Organic } \\ \text { substrate }\end{array} & \begin{array}{c}\text { Thiosulphate } \\ \text { consumed } \\ (\mathrm{mM})\end{array} & \begin{array}{c}\text { Nitrate } \\ \text { provided } \\ (\mathrm{mM})\end{array} & \begin{array}{c}\text { Nitrate } \\ \text { required* }\end{array} & \begin{array}{c}\text { Increase in OD } \\ \text { over single } \\ \text { substrate }\end{array} & \begin{array}{c}\text { Detectable } \\ \text { nitrate } \\ \text { remaining }\end{array} & \begin{array}{c}\text { Nitrite } \\ \text { produced } \\ (\text { concn })\end{array}\end{array}$

\begin{tabular}{|c|c|c|c|c|c|c|c|c|}
\hline Succinate $†$ & 4 & - & 20 & $7 \cdot 3(35 \%)$ & & + & & $.7 \mathrm{~mm}$ \\
\hline Succinate & 4 & $7 \cdot 5$ & 20 & $19.3(35 \%)$ & $29 \%$ & - & $<10$ & $\mu \mathrm{M}$ \\
\hline Acetate† & 20 & - & 20 & $20.8(35 \%)$ & & + & & $4 \mathrm{mM}$ \\
\hline Acetate & 20 & $2 \cdot 5$ & 20 & $24.8(35 \%)$ & $32 \%$ & - & $<10$ & $\mu \mathrm{M}$ \\
\hline Formate $\nmid 7$ & 75 & - & 40 & $27 \quad(10 \%)$ & & + & 1 & $\mathrm{mM}$ \\
\hline Formate 7 & 75 & $8 \cdot 5$ & 40 & $40.6(10 \%)$ & $33 \%$ & - & $<10$ & $\mu \mathbf{M}$ \\
\hline
\end{tabular}

* The nitrate requirement was based on the total substrate consumption and was corrected for carbon assimilation. The assumed values for carbon assimilation are given in parentheses.

$\dagger$ Thiosulphate not provided.

The theoretical balances for total oxidation of these substrates using nitrate are:

$$
\begin{gathered}
5\left(\mathrm{CH}_{3} \mathrm{COO}^{-}\right)_{2}+14 \mathrm{NO}_{3}^{-} \rightarrow 7 \mathrm{~N}_{2}+20 \mathrm{CO}_{2}+14 \mathrm{OH}^{-}+\mathrm{H}_{2} \mathrm{O} \\
5 \mathrm{CH}_{3} \mathrm{COO}^{-}+8 \mathrm{NO}_{3}^{-} \rightarrow 4 \mathrm{~N}_{2}+10 \mathrm{CO}_{2}+8 \mathrm{OH}^{-}+6 \mathrm{H}_{2} \mathrm{O} \\
5 \mathrm{HCOOH}^{-}+2 \mathrm{NO}_{3}^{-} \rightarrow 5 \mathrm{CO}_{2}+\mathrm{N}_{2}+2 \mathrm{OH}^{-}+4 \mathrm{H}_{2} \mathrm{O} \\
5 \mathrm{~S}_{2} \mathrm{O}_{3}^{2-}+8 \mathrm{NO}_{3}^{-}+\mathrm{H}_{2} \mathrm{O} \rightarrow 9 \mathrm{SO}_{4}^{2-}+\mathrm{H}_{2} \mathrm{SO}_{4}+4 \mathrm{~N}_{2}
\end{gathered}
$$


Table 4. RuBPcase activities found in extracts from Thiosphaera pantotropha (strain GB17) grown under different conditions

$\begin{array}{cc}\text { Growth } & \text { Growth } \\ \text { conditions } & \text { phase }\end{array}$

Aerobic Exponential

Anaerobic Exponential

Anaerobic Exponential

Anaerobic Late-stationary

Aerobic End-exponential

Anaerobic End-exponential

\author{
Substrate and \\ concn (mM)
}

Thiosulphate, 20

Thiosulphate, 10

Sulphide, $8 \cdot 5$

Thiosulphate, 10

Acetate, 10

Acetate, 10

ND, Not detectable.

\author{
RuBPcase activity \\ [nmol $\mathrm{CO}_{2}$ fixed $\mathrm{min}^{-1}(\mathrm{mg} \text { protein })^{-1}$ ]
}

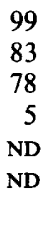

99

78

5

ND

ND

The utilization of thiosulphate during the denitrification on mixed substrates by Thiobacillus A2 was supported by results obtained in the substrate screening programme when mixotrophic cultures showed a $30 \%$ increase in OD over acetate-, fructose- or succinate-grown cultures, together with thiosulphate consumption (Table 3). Sulphur was not observed in these cultures.

The amounts of RuBPcase found in strain GB17 cells batch-grown under different conditions are shown in Table 4.

\section{DISCUSSION}

The new isolate, strain GB17, is able to utilize both organic substrates and reduced sulphur compounds under aerobic and anaerobic conditions. The amounts of RuBPcase found in cells grown anaerobically in batch culture are about half those obtained from aerobic cells, and sufficient to support growth. The very low amount of RuBPcase found in cells from latestationary phase cultures shows that the stage of growth of the cells when harvested is critical, and confirms similar observations by McFadden \& Denend (1972). The yields of protein obtained with strain GB17 under anaerobic conditions compare favourably with the yields from batch (Loya, 1979) and chemostat (Kuenen, 1979) cultures of Thiobacillus A2 grown aerobically. They are also in the same order of magnitude as yields of the aerobic obligate chemolithotrophs or the autotrophic denitrifyer, Thiomicrospira denitrificans, although half that obtained with $T$. denitrificans under anaerobic conditions (Timmer ten Hoor, 1977). These results clearly show that strain GB17 is a facultatively anaerobic, facultative autotroph of the type predicted in the Introduction. However, the importance of organisms of this metabolic type in the effluenttreatment system remains to be established. Attempts to isolate an obligate autotroph have so far failed.

During comparisons with strain GB17, it was found that, in contrast to previous reports (Taylor \& Hoare, 1969), the strain of Thiobacillus A2 used in these experiments can also use thiosulphate, at least mixotrophically, under anaerobic conditions. However, contrasting results have been obtained by A. P. Wood \& D. P. Kelly (personal communication) with another strain, and further studies to provide clarification are in progress. The ability of $P$. denitrificans to grow aerobically on thiosulphate has only recently become known (Friedrich \& Mitrenga, 1981). Although we have been able to confirm this observation, attempts to culture this organism anaerobically on reduced sulphur compounds have so far failed.

The contrast in the times required before gas production appears after aerobic culture suggests that strain GB17 is better adapted for anaerobic growth in a variable environment than is Thiobacillus A2. Preliminary studies indicate that its denitrifying properties are constitutive as similarly reported for Thiomicrospira denitrificans (Timmer ten Hoor, 1975). Since the effluenttreatment system is normally an anaerobic environment which is occasionally contaminated with oxygen, the ecological advantage would be taken by the species whose nitrate reductase synthesis is not repressed by the presence of oxygen. Should the enzyme prove to be constitutive, strain GB17 might more accurately be termed a facultative aerobe than a facultative anaerobe. 
One interesting point that arose during substrate screening was the ability of all three species to utilize acetone as their sole source of carbon and energy under anaerobic conditions. It had previously been considered that the initial step of acetone metabolism requires an oxygenase reaction (Taylor et al., 1980). Since all three species tested had this property, it would appear that the ability to utilize acetone anaerobically may be widespread, although not universal since we confirmed that the organism used by Taylor et al. (1980), bacterium A1, grew anaerobically on acetate but not acetone (unpublished results). The pathway of anaerobic acetone metabolism in these organisms is currently under investigation in this laboratory.

A comparison between strain GB17, Thiobacillus A2 and P. denitrificans showed that although all three are very versatile in their substrate metabolism, and a fair degree of overlap in their substrate range was to be expected, significant differences do occur. The fact that strain GB17 is a coccus means that it falls outside the genus description for Thiobacillus. The many differences between strain GB17 and $P$. denitrificans, including anaerobic sulphur metabolism and use of fumarate as an electron acceptor argue against classification of the new isolate as a Paracoccus. Moreover, the ability to denitrify with hydrogen as an energy source has also been reported for a third, totally different species, Alcaligenes eutrophus (Pfitzner \& Schlegel, 1973). Although Friedrich \& Mitrenga (1981) have commented that the ability to oxidize thiosulphate may be more widespread than previously thought, and therefore not selective enough a property to permit classification of a group of organisms, insufficient evidence is currently available to make a judgement. We therefore propose to form a new genus, Thiosphaera, to accommodate isolate GB17 in recognition of its sulphur metabolism. In view of its versatility, it has been given the species name pantotropha. A culture has been deposited in the Delft Culture Collection under this name, and has been designated the type species of the genus. It has the collection number LMD 82.5.

\section{Description of the genus Thiosphaera}

Thi.o.sphae'ra Gr. noun thion sulphur; Gr. noun sphaera a sphere. Thiosphaera a sulphur sphere.

Cells coccoid, occurring singly, in pairs and in chains. Usually non-motile. Gram-negative. Metabolism respiratory, able to use oxygen, nitrate, nitrite or a nitrogen oxide as the terminal electron acceptor. Able to oxidize reduced sulphur compunds as an energy source for growth. $\mathrm{CO}_{2}$ can serve as the sole carbon source. Oxidase- and catalase-positive.

Type species Thiosphaera pantotropha LMD 82.5 (Delft Culture Collection) pan.to'troph.a Gr. prefix panto all; Gr. noun trophos feeder; M.L. adj. pantotrophus omnivorus. Description as in the above paper.

The authors would like to thank Mrs W. H. Batenburg-van der Vegte for doing the electron microscopy, Miss H. van Eyk and Ir J. van der Toorn for taxonomical asistance, and Drs G. M. H. Scheulderman-Suylen for constructive discussion. Additionally, thanks are due to Gist Brocades N.V., Delft, for making samples from their pilot plant effluent treatment system available to us.

\section{REFERENCES}

Aminudin, M. \& Nicholas, D. J. D. (1973). Sulphide oxidation linked to the reduction of nitrate and nitrite in Thiobacillus denitrificans. Biochimica et biophysica acta 325, 81-93.

Batchelor, B. \& LaWrence, A. W. (1978). A kinetic model for autotrophic denitrification using elemental sulphur. Water Research 12, 1075-1084.

BEIJERINCK, W. M. (1910). Bildung und Verbrauch von Stickoxydul durch Bakterien. Centrallblatt für Bakteriologie (Abteilung II) 25, 30-63.

Beudeker, R. F., Cannon, G. C., Kuenen, J. G. \& SHIVELY, J. M. (1980). Relations between D-ribulose1,5-bisphosphate carboxylase, carboxysomes and $\mathrm{CO}_{2}$-fixing capacity in the obligate chemolithotroph Thiobacillus neapolitanus grown under different limi- tations in the chemostat. Archives of Microbiology 124, 185-189.

Beudeker, R. F., GotTschal, J. C. \& Kuenen, J. G. (1982). Reactivity versus flexibility in Thiobacilli. Antonie van Leeuwenhoek 48, 39-51.

BranNan, D. K. \& Caldwell, D. E. (1980). Thermothrix thiopara: growth and metabolism of a newly isolated thermophile capable of oxidising sulphur and sulphur compounds. Applied and Environmental Microbiology 40, 211-216.

Friedrich, C. G. \& Mitrenga, G. (1981). Oxidation of thiosulphate by Paracoccus denitrificans and other hydrogen bacteria. FEMS Microbiology Letters 10 , 209-212.

GotTschal, J. C., de VRies, S. \& Kuenen, J. G. 
(1979). Competition between the facultatively chemolithotrophic Thiobacillus A2, an obligately chemolithotrophic Thiobacillus and a heterotrophic spirillum for inorganic and organic substrates. Archives of Microbiology 121, 241-249.

Griess-Romisn-van ECK, (1966). Physiological and chemical tests for drinking water. NEN 1056, IV-2. Nederlands Normalisatie - Instituut Rijswijk.

IsHAQUE, M \& ALEEM, M. I. H. (1973). Intermediates of denitrification in the chemo-autotroph Thiobacillus denitrificans. Archiv für Mikrobiologie 94, 269-282.

JustiN, P. \& Kelly, D. P. (1978). Metabolic changes in Thiobacillus denitrificans accompanying the transition from aerobic to anaerobic growth in continuous chemostat culture. Journal of General Microbiology 107, 131-138.

KUENEN, J. G. (1979). Growth yields and "maintenance energy requirement" in Thiobacillus species under energy limitation. Archives of Microbiology 122, 183-188.

LOYA, S. (1979). Chemoautotrophy versus chemoheterotrophy in Thiobacillus A2. Ph.D thesis, Tel Aviv University, Israel.

MCFadden, B. A. \& Denend, A. R. (1972). Ribulose diphosphate carboxylase from autotrophic microorganisms. Journal of Bacteriology 110, 633-642.

Pfitzner, J. \& Schlegel, H. G. (1973). Denitrifikation bei Hydrogenomonas eutropha stam H16. Archiv für Mikrobiologie 90, 199-211.

RHEE, G-Y. \& FuHS, G. W. (1978). Wastewater denitrification with one-carbon compounds as energy source. Journal of the Water Pollution Control Federation 50, 2111-2119.

SöRBO, B. (1957). A colorimetric method for the determination of thiosulphate. Biochimica et biophysica acta 23, 412-416.
Sørensen, J., Tiedje, J. M. \& Firestone, R. B. (1980). Inhibition by sulphide of nitric and nitrous oxide reduction by denitrifying Pseudomonas fluorescens. Applied and Environmental Microbiology 39, 105-108.

TAYLOR, B. F \& HOARE, D. S. (1969). New facultative Thiobacillus and a reevaluation of the heterotrophic potential of Thiobacillus novellus. Journal of Bacteriology 100, 487-497.

TAYlor, B. F., HoARE, D. S. \& Hoare, S. L. (1971). Thiobacillus denitrificans as an obligate chemolithotroph. 1. Isolation and growth studies. Archiv für Mikrobiologie 78, 193-204.

Taylor, D. G., Trudgill, P. W., Cripps, R. E. \& HaRRIS, P. R. (1980). The microbial metabolism of acetone. Journal of General Microbiology 118, 159170.

Timmer ten Hoor, A. (1975). A new type of thiosulphate oxidizing, nitrate-reducing microorganism: Thiomicrospira denitrificans sp. nov. Netherlands Journal of Sea Research 9, 344-350.

TIMMER TEN HOOR, A. (1977). Denitrificerende kleurloze zwavelbacterien. Ph.D thesis, Groningen University, The Netherlands.

TRÜPER, H. G. \& SCHLEgel, H. G. (1964). Sulphur metabolism in Thiorhodaceae. 1. Quantitative measurements on growing cells of Chromatium okenii. Antonie van Leeuwenhoek 30, 225-238.

VISHNIAC, W. V. (1974). Organisms metabolizing sulfur and sulfur compounds. In Bergey's Manual of Determinative Bacteriology, 8th edn, pp. 456-461. Edited by R. E. Buchanan \& N. E. Gibbons. Baltimore: Williams \& Wilkins.

Vishniac, W. \& SANTER, M. (1975). The Thiobacilli. Bacteriological Reviews 21, 195-213. 